\title{
DEFINING TRANSPORT LOGISTICS: A LITERATURE REVIEW AND PRACTITIONER OPINION BASED APPROACH
}

\author{
Darja TOPOLŠEK ${ }^{*}$, Kristina ČIŽIŪNIENĖ ${ }^{2}$, Tina CVAHTE OJSTERŠEK ${ }^{3}$ \\ ${ }^{1,3}$ Faculty of Logistics, University of Maribor, Slovenia \\ ${ }^{2}$ Dept of Department of Logistics and Transport Management, Vilnius Gediminas Technical University, Lithuania
}

Received 27 June 2018; revised 17 November 2018; accepted 20 November 2018

\begin{abstract}
There are many concepts in the transport and logistics business: transport, logistics, transportation, forwarding, etc. There are also a number of different study programs and disciplines such as: transport economics, transport logistics, logistics management, etc. All of these titles are often related to the content of the plan, planning, organization, management and control of the movement of human, material, informational and financial flows. However, in practice, they are often correlated and misused. Therefore, it is an important task to properly define these concepts. This article, based on various scientific literature, deals with the concept of transport logistics in various disciplines and fields of research. The results of this analysis made it possible to identify that there is no unified logistic term. Therefore, a qualitative study was also used. The purpose of this study is to identify the concept of transport/logistics companies in the Baltic States as the concept is treated in business. The results of the research have shown that the concept of transport logistics is also understood differently. Therefore, the purpose of this article is to formulate the definition of transport logistics on the basis of the results of the scientific literature analysis and qualitative research.
\end{abstract}

Keywords: transport, logistics, definition, database, literature review.

\section{Introduction}

In its beginning phases, logistics was often connected only with its two functions of transport and warehousing. Later, (Christopher 2016) defined logistics as "the process of strategically managing the movement and storage of materials, parts and finished inventory from suppliers, through the firm and on to customers". As such, logistics is not just another name for transport, which is also confirmed by the assessment of ELA/A. T. Kearney (2004), which estimated that transport presents approximately $40 \%$ of all logistics costs. Transport is a part of integrated logistics management and is of crucial importance as such. It is not only limited to flow of goods across space and is not only a connective function in the fields of delivery of raw materials for manufacturing needs and for distributing final products. It is a part of adding value, which is included into strategic management and decisions through transport logistics. A well developed transport system ensures better efficiency, a reduction of operating costs, and higher service quality of logistics systems (Tseng et al. 2005). Therefore, the transport function has undergone structural changes, which are reflected in the development of transport logistics (Chatterjee, Tsai 2002). Today, transport itself is regarded as one of the major components of distribution and logistics. Taking into account all of the major components of a logistics system, such as warehousing, inventory, packaging, and information flows in addition to transport, planning them in a systematic way, and at the same time respecting constraints of appropriate costs and service levels, is the core task of modern logistics (Rushton et al. 2014). Many authors have been using the term "transport logistics" (Lai et al. 2004; Ehnert et al. 2006; Wong et al. 2009b; Lun et al. 2009) but they do not define it or identify its activities. Button (2010) finds that definitions of transport logistics are not always accurate, but there is one useful idea from a British logistics expert, Jim Cooper, who defined transport logistics as the "relationship between transport and integrated approaches to logistics and supply chain management". In other words, the main focus is on movement of goods in a supply chain, which is more than mere transport of goods, since it covers full business and operational frames within which the movement or movement of the cargo is planned, managed

${ }^{*}$ Corresponding author. E-mail: darja.topolsek@um.si

This is an Open Access article distributed under the terms of the Creative Commons Attribution License (http://creativecommons.org/licenses/by/4.0/), which permits unrestricted use, distribution, and reproduction in any medium, provided the original author and source are credited. 
and ultimately carried out (Button 2010). Transport logistics could therefore be considered as a broader term than transport alone, but a subactivity of logistics and supply chain management.

The European transport logistics sector contributes significantly to the European economy and is highly dependent on the external environment that shapes the needs and patterns for production and consumption of goods (EC 2015). EU's Freight Transport Logistics Action Plan defines transport logistics as planning, organization, management, control, and execution of freight transport operations in the supply chain (EC 2007). The long-term goal of transport logistics in $\mathrm{EU}$ is to lower the congestion, pollution, and noise, as well as $\mathrm{CO}_{2}$ emissions and to limit the dependence on fossil fuels. One of the most important drivers in European transport logistics is the development of Information and communications technology (ICT) systems that act as means of integration of the links in the logistics and supply chain (EUTRALOG 2005).

The fact that the term "transport logistics" seems to be often used, but not yet defined, shows an important gap in the accessible literature. To better understand the term "transport logistics", its meaning, and how it is used in various disciplines and research fields, this paper reviews accessible relevant academic literature. Guided by bibliometrics, the paper identifies most influential thinkers and publications on this growingly researched field. Additionally, results of a research carried out in the transport and logistics companies of the Baltic States will be presented. An overview of various fields indicated that there is currently no common definition of the term "transport logistics", therefore constructing a common definition, is the goal of the presented research.

\section{Materials and methods}

A literature review was performed in order to:

- determine the theoretical origin of the term "transport logistics";

- identify the most important or most influential studies;

- find potential definitions of the term;

- develop a literature-based definition of transport logistics.

The Clarivate Analytics Web of Science (WoS) citation database was used to obtain information and find literature. Transport logistics related literature was identified in the whole database from the year 1970 to March 2017. Jacso (2005) also mentions two other databases: Google Scholar, which he finds is not appropriate for purposes such as ours, and Scopus, which he finds gives similar results with a smaller coverage than WoS. WoS is used as a primary database in most bibliometric research McCain (1991), White (2003), White et al. (2004), RamosRodriguez and Ruíz-Navarro (2004), Biehl et al. (2006), Fernandez-Alles and Ramos-Rodriguez (2009), Polites and Watson (2009).
The search for use of the term "transport logistics" was performed with the search string "transportation logistics" or "transport logistics" (in the "topic" area). WoS gave 426 relevant results of publications of various scopes (i.e. articles, book chapters, conference proceedings, reviews, and editorials). Considering the rapid development of logistics and transport logistics in particular, it is possible that additional literature was published from the time of performing this research.

The dataset of relevant literature was used to perform a co-citation analysis, which is used for evaluation of scientific literature in a quantitative manner. The main idea of co-citation analysis is that publications with shared references are in an intellectual relationship Small (1973), Noyons (2001), Newell and Cousins (2015). Therefore, the analysis focuses on finding the incurrences of two or more publications being cited together in another publication, with a consequent result of identifying impactful publications and authors in a certain field.

The bibliometric software Bibexcel (Persson et al. 2009) was used for estimating co-citations. Bibexcel created files were imported open-source software Pajek - Program for Large Network Analysis (Batagelj, Mrvar 1998; De Nooy et al. 2018), which enables visualization and analysis of a network of co-citations and consequently shows the literature's "intellectual structure" (Yu et al. 2013). In the software output visualization, node size in the displayed network presents the degree of centrality of a node (the number of edges that connect to a node), which points to the node's (in our case a publication's) importance or influence.

All 426 academic publications were reviewed in order to identify whether they contain a definition of transport logistics or the publication only finds various relations of other logistics elements in relation to transport logistics and does not actually define it. Publications were eliminated from the set if:

- they did not contain a definition of transport logistics;

- the publication used another scholar's definition.

This analysis only found two definitions of transport logistics. Due to the minimal number of definitions the search was expanded using the Google Scholar tool, which also takes into account various other academic resources. The search string was the same as in WoS and was also performed in the German language. This broadened the number of results. Table 1 therefore shows the two publications found in WoS including the set definition and the number of citations, and additionally gives definitions from other academic resources: books (Table 2), online reports (Table 3).

In comparing the given definitions, it was found that no single definition precisely defines the meaning and elements of transport logistics. Consequently, a need to prepare a universal definition can be identified, and this is the goal of the present paper. 
Table 1. Definitions of transport logistics in WoS

\begin{tabular}{|c|c|c|}
\hline Reference & $\begin{array}{l}\text { Citation count } \\
\text { from WoS } \\
\text { (on } 29 \text { September 2017) }\end{array}$ & Definition \\
\hline $\begin{array}{l}\text { Lin } \\
(2016)\end{array}$ & none & $\begin{array}{l}\text { "... international transport logistics service systems providing import/export and } \\
\text { transhipment services engage in multi-country consolidation and warehousing functions } \\
\text { and integrate manufacturing industries to provide high value-adding, deep reprocessing } \\
\text { services to cargos". }\end{array}$ \\
\hline $\begin{array}{l}\text { Lai et al. } \\
(2002)\end{array}$ & $\begin{array}{l}149 \text { (note: a variant } \\
\text { of this definition } \\
\text { is repeated in Lai et al. } \\
\text { (2004) with } 67 \text { citations } \\
\text { in WoS) }\end{array}$ & $\begin{array}{l}\text { "Transport logistics in a supply chain is usually an intermediary that facilitates the } \\
\text { physical flows of goods from a point of origin, i.e., shipper, to a point of destination, } \\
\text { i.e., consignee. Firms in transport logistics perform the physical distribution function } \\
\text { to move goods from one place to another (Coyle et al. 1996) and the business process } \\
\text { spans organizational boundaries, encompassing shippers and consignees". } \\
\text { "The goal of a transport logistics service provider is to satisfy the customers (both } \\
\text { upstream and downstream) in the chain with greater effectiveness and efficiency than } \\
\text { the competitors". }\end{array}$ \\
\hline
\end{tabular}

Table 2. Definitions of transport logistics in books

\begin{tabular}{|c|c|c|}
\hline Reference & $\begin{array}{l}\text { Citation count } \\
\text { from WoS } \\
\text { (on 29 September 2017) }\end{array}$ & Definition \\
\hline $\begin{array}{l}\text { Kappauf et al. } \\
\text { (2011) }\end{array}$ & $\mathrm{n} / \mathrm{a}$ & $\begin{array}{l}\text { "Transport logistics, in a cross-sectional function, takes on the task of booking the } \\
\text { transport planning and the transport itself. At the end of the sales procedure, an invoice } \\
\text { is produced for the customer". } \\
\text { "... with the transport logistics goal of providing the required material to the right place } \\
\text { at the right time as inexpensively as possible..... }\end{array}$ \\
\hline $\begin{array}{l}\text { Button } \\
(2010)\end{array}$ & $\mathrm{n} / \mathrm{a}$ & $\begin{array}{l}\text { "transport logistics, ..., is the adoption of transport economic principles within larger } \\
\text { supply-chain concept". } \\
\text { "... it involves the movement of goods through the supply chain, bur is more than } \\
\text { just the freight transport aspect and embraces the full commercial and operational } \\
\text { frameworks within which the movement of goods is planned, managed and finally } \\
\text { carried out". }\end{array}$ \\
\hline $\begin{array}{l}\text { Baumgarten } \\
\text { (2008) }\end{array}$ & $\mathrm{n} / \mathrm{a}$ & $\begin{array}{l}\text { The author argues that transport logistics in a narrow sense deals with physical } \\
\text { transport of goods (in hard, liquid or gassy state) among different locations in logistics } \\
\text { networks. }\end{array}$ \\
\hline $\begin{array}{l}\text { Coyle et al. } \\
\text { (1996) }\end{array}$ & $\mathrm{n} / \mathrm{a}$ & $\begin{array}{l}\text { The authors find that transport logistics performs an intermediary role in the supply } \\
\text { chain since it enables physical flow of goods from the source point (suppliers) to the } \\
\text { point of use (destination or consumer). Businesses in transport logistics perform the } \\
\text { physical function of distribution, which means moving goods from one point to the } \\
\text { other. }\end{array}$ \\
\hline
\end{tabular}

Table 3. Definitions of transport logistics in online reports

\begin{tabular}{|l|l|l|}
\hline \multicolumn{1}{|c|}{ Reference } & $\begin{array}{c}\text { Citation count } \\
\text { from WoS } \\
\text { (on 29 September 2017) }\end{array}$ & Definition \\
\hline $\begin{array}{l}\text { Lagneaux } \\
(2008)\end{array}$ & $\mathrm{n} / \mathrm{a}$ & $\begin{array}{l}\text { “. freight transport logistics, tackling sectors clearly identified in the NACE } \\
\text { classification 14 as transport-bound logistics sectors, all coming under the so-called } \\
\text { freight transport logistics cluster. Transport logistics is seen as the organisation of flows } \\
\text { of goods and information across these functions". }\end{array}$ \\
\hline $\begin{array}{l}\text { Giannopoulos } \\
(2008)\end{array}$ & $\begin{array}{l}\text { "Co-modal Transport Logistics (CTL) can be defined today (after years of application } \\
\text { or mis-application of the term) as the adoption of techniques, actions, and methods } \\
\text { forming a global approach to the management and information transfer of the whole } \\
\text { physical circulation of goods: from raw materials, to components, to finished products } \\
\text { sold to consumers, and spare parts for these products. The interesting part of this } \\
\text { "global" definition is that Logistics includes the management of physical flows as well } \\
\text { as the management of information and financial flows. Its aim is defined to design a } \\
\text { cost effective organization able to handle the whole physical circulation of goods and } \\
\text { information flows that will ultimately provide consumers with the right level of service". }\end{array}$ \\
\hline $\begin{array}{l}\text { Muller-Jentsch } \\
(2002)\end{array}$ & $\begin{array}{l}\text { "Transport logistics is concerned with the management and optimization of transport } \\
\text { flows". }\end{array}$ \\
\hline
\end{tabular}


End of Table 3

\begin{tabular}{|l|c|l|}
\hline Reference & $\begin{array}{c}\text { Citation count } \\
\text { from WoS } \\
\text { (on 29 September 2017) }\end{array}$ & \multicolumn{1}{c|}{ Definition } \\
\hline $\begin{array}{l}\text { Chatterjee, } \\
\text { Tsai (2002) }\end{array}$ & $\mathrm{n} / \mathrm{a}$ & $\begin{array}{l}\text { "The objective of transportation logistics, one component of integrated logistics } \\
\text { management, is to compress time along the whole supply chain. This involves not only } \\
\text { reducing delivery time in shipments from suppliers of raw materials, intermediate goods } \\
\text { and components to factories, but also the distribution of final products from factories to } \\
\text { wholesalers, retailers and end users. It also includes distribution of spare parts to repair } \\
\text { establishments for after sales service”. }\end{array}$ \\
\hline $\begin{array}{l}\text { De Castro } \\
\text { (1993) }\end{array}$ & $\begin{array}{l}\text { "Transport logistics encompass all steps in the transfer of freight ... and the interaction } \\
\text { between the various institutions intervening in international freight transport, the } \\
\text { operators transporting it, and the transport intermediaries providing brokerage } \\
\text { services between freight transfers. Consequently, the customs administration, insurance } \\
\text { companies, banks, parastatal transport operators, terminal operators, Shippers' Councils, } \\
\text { private carriers, and intermediaries are considered as intervening in transport logistics". }\end{array}$ \\
\hline
\end{tabular}

\section{Transport logistics research: important research and definitions}

Even though the concept of transport logistics has a long history, the first recorded mention of the term was in 1977, when Mundy et al. (1977) researched evaluation by business executives of courses offered in a large transportation/logistics curriculum. Further scientific research brought the publication of the transportation logistics for spent-fuel storage and disposal by Andrews et al. (1978). Research by Lai et al. (2002) is the largest node on the cocitation network (Figure), which points to the importance of this publication for the transport logistics field. The authors researched measures of supply chain performance in a transport logistics setting and constructed a measuring instrument for effectiveness and efficiency of transport logistics shippers, service providers and consignees.

The paper by Lai et al. (2002), related to measures for evaluating supply chain performance in transport logistics, is the only work found on WoS that defines transport logistics and its meaning in the supply chain to a certain extent. It does not however give a definition of transport logistics as such and does not describe its activities.

Figure shows the visualization of the network of publications on the topic of transport logistics. It is based on the dataset of publications from WoS and shows cited references in the publications as nodes (circles), while the connective lines show when two publications are referenced in a publication together. The size of the node points to its centrality in the body of literature (number of connections). The general layout is based on the Force Atlas algorithm, which shows a closer relationship among nodes by clustering them closer together. Additionally, publications in closer relation are shown in the same colour.

It is evident from the figure that Lai et al. (2002), which is also the paper which gives the clearest definition of transport logistics, is the most important resource among the complete body of literature on transportation logistics, as its node is largest and very interconnected, closely followed by the 2004 paper from the same authors, giving the same definition (Lai et al. 2004).
As mentioned, the literature review revealed a smaller number of partial definitions of transport logistics (Tables 1-3). Studying these definitions, as well as studying publications that cite them, led to recognition that a precise definition of transport logistics does not exist. This is not surprising considering the fact that there are many challenges connected to defining transport logistics, one of which is the large number of disciplines that are involved in the transport logistics field. Surprisingly however, the use of the term "transport logistics" is quite common despite the lack of its definition.

\section{Exploratory research in Baltic States transport and logistics companies, according transport logistics definition}

The analysis of literature sources has been carried out and showed that there is no unified transport logistics defined. In order to find out how much this activity is relevant in practice (business), an exploratory survey also was selected using questionnaires. Qualitative exploratory research was carried out in order to find out how the leaders of the transport / logistics sector in the Baltic States define the concept of transport logistics.

The level of knowledge of transport logistics in practice is very low (EUTRALOG 2005), and should be increased. Taking into account that there are lot of transport and logistics companies in the Baltic States (Lithuania, Latvia, Estonia), they were selected for the survey by evaluating their websites, in which were indicated that the company provides transport logistic services. Knowing that when conducting is online, and probability that the answer to the whole questionnaire is not high, and then larger companies were selected, and after it has been sent out 70 questionnaires. Total completed questionnaires returned 166.

Since a qualitative research was conducted, the aim was to evaluate not just how many respondents responded, but how to get an image - how they understood the concept of "transport logistics". From all possible answers, similar definitions are grouped and are presented as a result. 


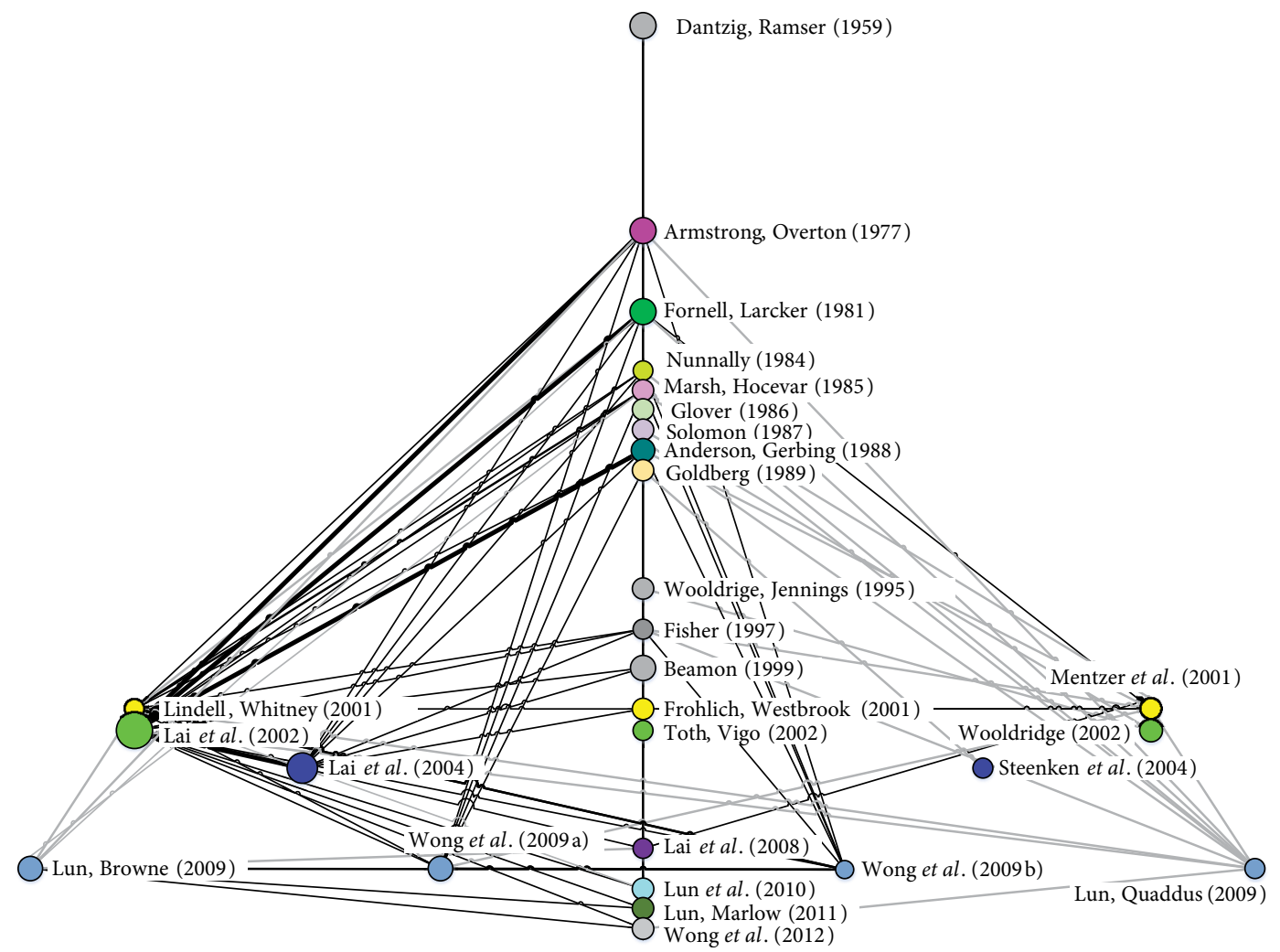

Figure. Visualization of the network of publications in the field of transport logistics (source: compiled by the authors)

Therefore, the results from all the questionnaires are presented and the following definitions are given:

- transport logistics - routing and control;

- transport logistics is the process by which logistics costs are optimized for transportation of goods, as well as management of information and time;

- transport logistics is the whole process of transport operations, from the raw material and up to when it is turned into a product;

- transport logistics is a subtlety of cargo movement;

- transport logistics is the door-to-door cargo transportation, as well as the processing of documents and ensuring optimal time, market and price;

- transport logistics is preparation, sorting, packaging, distribution, transportation, storage, etc.;

- transport logistics is the organization and management of all supply chains from raw materials to delivery to the place of consumption;

- transport logistics is a process associated with the market for transport services, the selection of the required vehicle, rational organization of freight transportation on time from point $\mathrm{A}$ to $\mathrm{B}$ at minimal cost;

- transport logistics is the process of ensuring the flow of goods from the time of loading to the place of delivery;

- transport logistics is a process in which a good, quick and thoughtful assessment of the current situation and a solution is made that provides the best possible result;
- transport logistics is a process that effectively plans a logistics chain from the initial service or point of sale to the end user.

The concept of transport logistics is widely used, but, as the results of the research show, the manager of each company understands and defines the concept differently. Therefore, such a different understanding of this concept could lead to major misunderstandings in providing services to customers and lead to difficulties in choosing the right company.

\section{Discussion: devising a definition of transport logistics}

When talking about transport logistics, keywords such as "movement of goods", "physical transfer of goods (from the point of origin to the point of use)", "physical distribution function", "moving goods from one location to another", and "transfer of cargo" are mentioned most often in scientific literature as well as with practitioners. These keywords mostly include the transport of goods, but others also include words from the fields of planning and management of transport of goods, such as "efficient distribution", "planning, managing and execution of movement of goods", "managing physical flow", and "managing and optimizing transport flows". Since transport, among other, also ensures spatial and time utility, key words such as "optimal delivery times" and "services rendered on time". In the frame of transport and logistics, other key 
words such as "minimal costs", "high effectiveness and efficiency", "cost effective organization", and "minimal human resources" also need to be included.

Considering the inconsistencies in the current body of literature and in business use, a consistent and common definition of the term "transport logistics" is certainly needed. It must include various aspects and concepts, connected with the term, in an inclusive yet adaptive way, so it encompasses all crucial elements and reflects slight differences in defining the scope of the term. With this in mind, the authors propose the following definition:

Transport logistics is a crucial part in the supply chain that in its essence organizes, manages, optimizes and ultimately performs physical distribution of goods and information through the whole upstream and downstream chain in an efficient and effective manner. Its activities and functions go beyond the traditional transport function in so that they also include integration with other supply chain functions such as warehousing, accounting, marketing or customer relations, while taking into account the organizational, financial, commercial and operational aspects of the supply chain as a whole.

\section{Conclusions}

European Union has highlighted the problem of the lack of knowledge in the field of transport logistics and therefore encourages different types of educational undertakings, which will help the sector to improve the image of European freight transport logistics companies (EC 2015). In accordance with this, the presented paper drew upon literature reviews and the practitioner perspective to find a common transport logistics definition, as is given in the previous chapter. General conclusions, deriver from the authors' work in this literature review and practitioner interviews, can be summed up in the following points:

- transport logistics, even though an often used term, has been shown in this paper to be lacking a commonly accepted definition in scientific literature as well as on a practitioner level;

- research identified only two scientific sources which give a definition of transport logistics, and consequently had to broaden the scope to include other academic resources, 11 altogether;

- there are also many companies that specialise in transport logistics, and in many cases this involves international activities as the 'global economy' grows and the supply chains grow longer and more complex. From the practitioner viewpoint, research in Baltic transport/logistics companies additionally showed that there is no unified definition of transport logistics. Not infrequently, this concept is often compared with the transportation process, routing and cost reduction opportunities;

- therefore, the authors believe that the work presented in this paper brings a most needed consolidation of scientific, academic and practitioner viewpoints into a proposed common definition of the term. This will importantly contribute to overcoming the current disparities in using the term in all spheres, mostly in comparison and in relation to logistics and transport alone;

- further research on the topic should broaden the area where practitioners were surveyed to achieve an even more global consensus, and also try and put the concept of transport logistics into a wider framework of supply chain management and logistics.

\section{References}

Anderson, J. C.; Gerbing, D. W. 1988. Structural equation modeling in practice: a review and recommended two-step approach, Psychological Bulletin 103(3): 411-423.

https://doi.org/10.1037/0033-2909.103.3.411

Andrews, W. B.; Burnett, R. A.; Engel, R. L. 1978. Transportation logistics for spent-fuel storage and disposal, Transactions of the American Nuclear Society 30: 292-293.

Armstrong, J. S.; Overton, T. S. 1977. Estimating nonresponse bias in mail surveys, Journal of Marketing Research 14(3):396402. https://doi.org/10.2307/3150783

Batagelj, V.; Mrvar, A. 1998. Pajek - a program for large network analysis, Connections 21(2): 47-57.

Baumgarten, H. 2008. Das Beste der Logistik: Innovationen, Strategien, Umsetzungen. Berlin: Springer-Verlag Berlin Heidelberg. 423 s. (in German).

https://doi.org/10.1007/978-3-540-78405-0

Beamon, B. M. 1999. Measuring supply chain performance, International Journal of Operations \& Production Management 19(3): 275-292. https://doi.org/10.1108/01443579910249714

Biehl, M.; Kim, H.; Wade, M. 2006. Relationships among the academic business disciplines: a multi-method citation analysis, Omega 34(4): 359-371.

https://doi.org/10.1016/j.omega.2004.12.002

Button, K. 2010. Transport Economics. Edward Edgar Publishing. $528 \mathrm{p}$.

Chatterjee, L.; Tsai, C.-M. 2002. Transportation Logistics in Global Value and Supply Chains. Center for Transportation Studies Boston University. 17 p. Available from Internet: http://www. bu.edu/transportation/WPSeries.html

Christopher, M. C. 2016. Logistics and Supply Chain Management. FT Press. 328 p.

Coyle, J. J.; Bardi, E. J.; Langley, C. J. 1996. Management of Business Logistics: A Supply Chain Perspective. Western Publishing Company.

Dantzig, G. B.; Ramser, J. H. 1959. The truck dispatching problem, Management Science 6(1): 80-91.

https://doi.org/10.1287/mnsc.6.1.80

De Castro, C. T. 1993. Trade and Transport Logistics Facilitation Guidelines. SSATP Working Paper No 4. The World Bank and Economic Commission for Africa. 72 p. Available from Internet: https:/www.ssatp.org/sites/ssatp/files/publications/ SSATP-WorkingPapers/SSATPWP04.pdf

De Nooy, W.; Mrvar, A.; Batagelj, V. 2018. Exploratory Social Network Analysis with Pajek: Revised and Expanded Edition for Updated Software. New York: Cambridge University Press. 455 p. https://doi.org/10.1017/9781108565691

EC. 2015. Fact-Finding Studies in Support of the Development of an EU Strategy for Freight Transport Logistics Lot 1: Analysis of the EU Logistics Sector. Final report. European Com- 
mission. 442 p. Available from Internet: https://ec.europa. eu/transport/sites/transport/files/themes/strategies/studies/ doc/2015-01-freight-logistics-lot1-logistics-sector.pdf

EC. 2007. Freight Transport Logistics Action Plan. Commission of the European Communities. 12 p. Available from Internet: https://eur-lex.europa.eu/legal-content/EN/TXT/PDF/?uri=C ELEX:52007DC0607\&from=EN

Ehnert, I.; Arndt, L.; Mueller-Christ, G. 2006. A sustainable management framework for dilemma and boundaries in autonomous cooperating transport logistics processes, International Journal of Environment and Sustainable Development 5(4): 355-371. https://doi.org/10.1504/IJESD.2006.011555

ELA/A. T. Kearney. 2004. Excellence in Logistics: Differentiation for Performance. European Logistics Association (ELA)/A. T. Kearney Management Consultants.

EUTRALOG. 2005. RT\&D Roadmaps for European Transport Logistics of the Future. Project funded by the European Community under the 'Competitive and Sustainable Growth' Programme (1998-2002). Mettle Groupe. 62 p. Available from Internet: https://trimis.ec.europa.eu/sites/default/files/project/documents/20090917_160746_12641_EUTRALOG\%20 -\%20Final\%20Report.pdf

Fernandez-Alles, M.; Ramos-Rodriguez, A. 2009. Intellectual structure of human resources management research: a bibliometric analysis of the journal Human Resource Management, 1985-2005, Journal of the Association for Information Science and Technology 60(1): 161-175.

https://doi.org/10.1002/asi.20947

Fisher, M. L. 1997. What Is the Right Supply Chain for Your Product?, Harvard Business Review (2): 105-116.

Fornell, C.; Larcker, D. F. 1981. Evaluating structural equation models with unobservable variables and measurement error, Journal of Marketing Research 18(1): 39-50. https://doi.org/10.2307/3151312

Frohlich, M. T.; Westbrook, R. 2001. Arcs of integration: an international study of supply chain strategies, Journal of Operations Management 19(2): 185-200.

https://doi.org/10.1016/S0272-6963(00)00055-3

Giannopoulos, G. A. 2008. The application of co-modality in Greece: a critical appraisal of progress in the development of co-modal freight centres and logistics services, Transition Studies Review 15(2): 289-301.

https://doi.org/10.1007/s11300-008-0003-8

Glover, F. 1986. Future paths for integer programming and links to artificial intelligence, Computers \& Operations Research 13(5): 533-549. https://doi.org/10.1016/0305-0548(86)90048-1

Goldberg, D. E. 1989. Genetic Algorithms in Search, Optimization, and Machine Learning. Addison-Wesley Professional. $432 \mathrm{p}$.

Jacso, P. 2005. As we may search - comparison of major features of the Web of Science, Scopus, and Google Scholar citationbased and citation-enhanced databases, Current Science 89(9): 1537-1547.

Kappauf, J.; Lauterbach, B.; Koch, M. 2011. Logistic Core Operations with SAP. Springer. $255 \mathrm{p}$.

https://doi.org/10.1007/978-3-642-18204-4

Lagneaux, F. 2008. Economic Importance of Belgian Transport Logistics. NBB Working Paper No 125. National bank of Belgium (NBB). 83 p. Available from Internet: https://www.nbb. be/doc/ts/publications/wp/wp125en.pdf

Lai, K.-H.; Bao, Y.; Li, X. 2008. Channel relationship and business uncertainty: evidence from the Hong Kong market, Industrial Marketing Management 37(6): 713-724.

https://doi.org/10.1016/j.indmarman.2007.05.017
Lai, K.-H.; Ngai, E. W. T.; Cheng, T. C. E. 2004. An empirical study of supply chain performance in transport logistics, International Journal of Production Economics 87(3): 321-331. https://doi.org/10.1016/j.ijpe.2003.08.002

Lai, K.-H.; Ngai, E. W. T.; Cheng, T. C. E. 2002. Measures for evaluating supply chain performance in transport logistics, Transportation Research Part E: Logistics and Transportation Review 38(6): 439-456.

https://doi.org/10.1016/S1366-5545(02)00019-4

Lin, S.-C. 2016. A fuzzy algorithm to evaluate competitive locations for international transport logistics system, Journal of Marine Science and Technology 24(2): 125-134.

https://doi.org/10.6119/JMST-015-0511-4

Lindell, M. K.; Whitney, D. J. 2001. Accounting for common method variance in cross-sectional research designs, Journal of Applied Psychology 86(1): 114-121.

https://doi.org/10.1037//0021-9010.86.1.114

Lun, Y. H. V.; Lu, C.-S.; Lai, K.-H. 2009. Introduction to the special issue on transport logistics and physical distribution, International Journal of Production Economics 122(1): 1-3. https://doi.org/10.1016/j.ijpe.2009.05.001

Lun, Y. H. V.; Browne, M. 2009. Fleet mix in container shipping operations, International Journal of Shipping and Transport Logistics 1(2): 103-118.

https://doi.org/10.1504/IJSTL.2009.024491

Lun, Y. H. V.; Quaddus, M. A. 2009. An empirical model of the bulk shipping market, International Journal of Shipping and Transport Logistics 1(1): 37-54. https://doi.org/10.1504/IJSTL.2009.021975

Lun, Y. H. V.; Lai, K.-H.; Cheng, T. C. E. 2010. Shipping and Logistics Management. Springer. 238 p.

https://doi.org/10.1007/978-1-84882-997-8

Lun, Y. H. V.; Marlow, P. 2011. The impact of capacity on firm performance: a study of the liner shipping industry, International Journal of Shipping and Transport Logistics 3(1): 57-71. https://doi.org/10.1504/IJSTL.2011.037819

Marsh, H. W.; Hocevar, D. 1985. Application of confirmatory factor analysis to the study of self-concept: First- and higher order factor models and their invariance across groups, Psychological Bulletin 97(3): 562-582.

https://doi.org/10.1037/0033-2909.97.3.562

McCain, K. W. 1991. Mapping economics through the journal literature: An experiment in journal cocitation analysis, Journal of the Association for Information Science and Technology 42(4): 290-296.

https://doi.org/10.1002/(SICI)1097-4571(199105)42:4<290:: AID-ASI5>3.0.CO;2-9

Mentzer, J. T.; DeWitt, W.; Keebler, J. S.; Min, S.; Nix, N. W.; Smith, C. D.; Zacharia, Z. G. 2001. Defining supply chain management, Journal of Business Logistics 22(2): 1-25. https://doi.org/10.1002/j.2158-1592.2001.tb00001.x

Muller-Jentsch, D. 2002. Transport Policies for the Euro-Mediterranean Free-Trade Area: An Agenda for Multimodal Transport Reform in the Southern Mediterranean. World Bank Technical Paper No. 527. Washington, DC, US. 183 p. Available from Internet: https://openknowledge.worldbank.org/handle/10986/15221

Mundy, R. A.; Langley, C. J.; Gibson, T. E. 1977. Industry evaluation of a transportation/logistics curriculum, Transportation Journal 17(1): 33-39.

Newell, J. P.; Cousins, J. J. 2015. The boundaries of urban metabolism: towards a political-industrial ecology, Progress in Human Geography 39(6): 702-728. https://doi.org/10.1177/0309132514558442 
Noyons, E. 2001. Bibliometric mapping of science in a policy context, Scientometrics 50(1): 83-98. https://doi.org/10.1023/A:1005694202977

Nunnally, J. C. 1984. Psychometric Theory. McGraw-Hill.

Persson, O.; Danell, R.; Scheider, J. W. 2009. How to use Bibexcel for various types of bibliometric analysis, in F. Åström, R. Danell, B. Larsen, J. Schneider (Eds.). Celebrating Scholarly Communication Studies: a Festschrift for Olle Persson at His 60th Birthday, 9-24.

Polites, G. L.; Watson, R. T. 2009. Using social network analysis to analyze relationships among IS journals, Journal of the Association for Information Systems 10(8): 595-636. https://doi.org/10.17705/1jais.00206

Ramos-Rodriguez, A.-R.; Ruíz-Navarro, J. 2004. Changes in the intellectual structure of strategic management research: a bibliometric study of the Strategic Management Journal, 1980-2000, Strategic Management Journal 25(10): 981-1004. https://doi.org/10.1002/smj.397

Rushton, A.; Croucher, P.; Baker, P. 2014. The The Handbook of Logistics and Distribution Management: Understanding the Supply Chain. Kogan Page. 720 p.

Small, H. 1973. Co-citation in the scientific literature: A new measure of the relationship between two documents, Journal of the Association for Information Science and Technology 24(4): 265-269. https://doi.org/10.1002/asi.4630240406

Solomon, M. M. 1987. Algorithms for the vehicle routing and scheduling problems with time window constraints, Operations Research 35(2): 254-265.

https://doi.org/10.1287/opre.35.2.254

Steenken, D.; Voß, S.; Stahlbock, R. 2004. Container terminal operation and operations research - a classification and literature review, OR Spectrum 26(1): 3-49. https://doi.org/10.1007/s00291-003-0157-z

Toth, P.; Vigo, D. 2002. The Vehicle Routing Problem. SIAM - Society for Industrial and Applied Mathematics. https://doi.org/10.1137/1.9780898718515

Tseng, Y.-Y.; Yue, W. L.; Taylor, M. A. P. 2005. The role of transportation in logistics chain, Proceedings of the Eastern Asia Society for Transportation Studies 5: 1657-1672.

White, H. D. 2003. Pathfinder networks and author cocitation analysis: a remapping of paradigmatic information scientists, Journal of the Association for Information Science and Technology 54(5): 423-434. https://doi.org/10.1002/asi.10228

White, H. D.; Wellman, B.; Nazer, N. 2004. Does citation reflect social structure? Longitudinal evidence from the "Globenet" interdisciplinary research group, Journal of the Association for Information Science and Technology 55(2): 111-126. https://doi.org/10.1002/asi.10369

Wong, C. W. Y.; Lai, K.-H.; Cheng, T. C. E. 2009a. Complementarities and alignment of information systems management and supply chain management, International Journal of Shipping and Transport Logistics 1(2): 156-171. https://doi.org/10.1504/IJSTL.2009.024493

Wong, C. W. Y.; Lai, K.-H.; Ngai, E. W. T. 2009b. The role of supplier operational adaptation on the performance of ITenabled transport logistics under environmental uncertainty, International Journal of Production Economics 122(1): 47-55. https://doi.org/10.1016/j.ijpe.2008.12.023

Wong, C. W. Y.; Lai, K.-H.; Lun, Y. H. V.; Cheng, T. C. E. 2012. A study on the antecedents of supplier commitment in support of logistics operations, International Journal of Shipping and Transport Logistics 4(1): 5-16.

https://doi.org/10.1504/IJSTL.2012.044132
Wooldrige, M.; Jennings, N. R. 1995. Intelligent agents: theory and practice, The Knowledge Engineering Review 10(2): 115152. https://doi.org/10.1017/S0269888900008122

Wooldridge, M. 2002. An Introduction to MultiAgent Systems. Wiley. 348 p.

Yu, C.; Davis, C.; Dijkema, G. 2013. Understanding the evolution of industrial symbiosis research, Journal of Industrial Ecology 18(2): 280-293. https://doi.org/10.1111/jiec.12073 